Review Article

\title{
Drug targets: ligand and voltage gated ion channels
}

\begin{abstract}
Department of Pharmacology, Jawaharlal Institute of Postgraduate Medical Education and Research (JIPMER), Puducherry, India

Received: 03 December 2016

Revised: 07 December 2016

Accepted: 27 December 2016

*Correspondence to:

Dr. Nilan T. Jacob,

Email:

nilantjacob20@gmail.com

Copyright: (C) the author(s), publisher and licensee Medip Academy. This is an openaccess article distributed under the terms of the Creative Commons Attribution NonCommercial License, which permits unrestricted noncommercial use, distribution, and reproduction in any medium, provided the original work is properly cited.
\end{abstract}

\author{
Nilan T. Jacob*
}

\begin{abstract}
The elucidation of a drug target is one of the earliest and most important steps in the drug discovery process. Ion channels encompassing both the ligand gated and voltage gated types are the second most common drug targets after GProtein Coupled Receptors (GPCR). Ion channels are basically pore forming membrane proteins specialized for conductance of ions as per the concentration gradient. They are further broadly classified based on the energy (ATP) dependence into active ion channels/pumps and passive ion channels. Gating is the regulatory mechanism of these ion channels by which binding of a specific molecule or alteration in membrane potential induces conformational change in the channel architecture to result in ion flow or its inhibition. Thus, the study of ligand and voltage gated ion channels becomes an important tool for drug discovery especially during the initial stage of target identification. This review aims to describe the ligand and voltage gated ion channels along with discussion on its subfamilies, channel architecture and key pharmacological modulators.
\end{abstract}

Keywords: Drug targets, Ion channels, Ligand gated ion channels, Receptor pharmacology, Voltage gated ion channels

\section{INTRODUCTION}

In the drug discovery process, the identification and validation of a drug target is a crucial element for better drug designing. As the search for newer drug targets continues, more than $50 \%$ of these identified targets belong to just 3 receptor families. G-Protein Coupled Receptors (GPCR) are the most common drug target identified, (Figure 1) followed by ion channels and nuclear receptors. ${ }^{1}$ Ion channels defined as pore containing membrane proteins, primarily function for ion conductance across cells in accordance with the concentration gradient (passive ion channels) or utilizes energy (ATP) to drive ion flow against the concentration gradient (active ion channels or pumps). The ion channel architecture comprises of multiple subunits each performing specified roles; the central subunit contains the pore for the ion flow and the ancillary subunits are involved in regulation of channel function by secondary mechanisms like phosphorylation. The subunits themselves are arranged as a homogenous group or as a heterogenous unit around the central pore. Each individual subunit comprises of multiple membranespanning or transmembrane segments that contains the ligand binding domains in ligand gated ion channels.

Gating refers to the mechanism of regulation of the ion channel function. These channels exist in 3 states namely open, closed/resting and inactive state. Certain ion channels undergo conformational change on binding with molecules and can thus switch between the three states (Figure 2)- open, closed/resting and inactive states within milliseconds. ${ }^{2}$ Such molecules called 'ligands' can either be extracellular (Nicotinic acetylcholine receptor) or intracellular (IP3 receptor) in origin and such channels 
are termed as ligand gated ion channels. Voltage gated ion channels are ion channels that are subject to conformational change based on changing membrane potential. Besides being significantly more rapid than ligand gated ion channels, voltage gated ion channels also exhibit highly selective permeability. The International Union of Basic and Clinical Pharmacology database (IUPHAR-DB) under the aegis of IUPHAR/BPS (British Pharmacological Society) describes a comprehensive list of drug targets identified till date and forms the framework of this review.

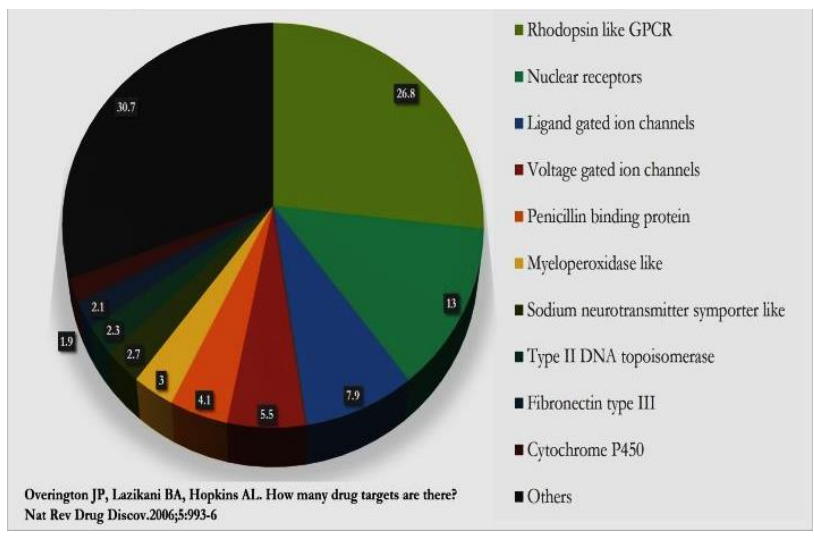

Figure 1: Gene family distribution of current drug targets.

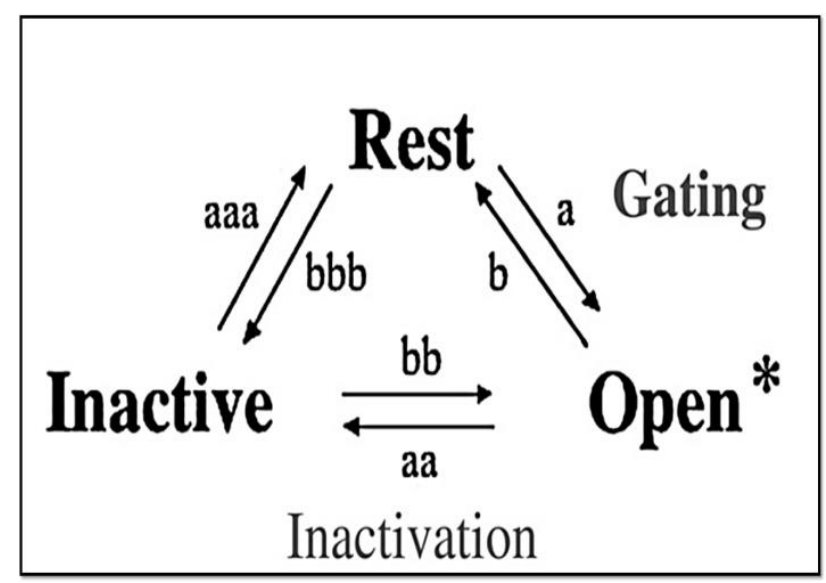
Figure 2: Transition of ion channels between
different states.

\section{LIGAND GATED ION CHANNELS}

Ligand gated ion channels are ion channels gated/regulated by the binding of extracellular or intracellular molecules, termed ligands. The ligands bind to the specific ligand binding domains located in the transmembrane segments of the channel subunits resulting in a conformational change that can switch the state of the channel between open and closed. Ligand gated ion channels are present in abundance in the central nervous system and are involved in several functions like anxiety, neuronal excitability, seizures, learning and memory. In majority of these channels in the CNS, the ligands are neurotransmitters like acetylcholine, glutamate, aspartate and GABA. Neurotransmitters are examples of extracellular ligands acting on the ion channels. On the other hand, intracellular ligands are commonly second messengers present inside the cell like inositol triphosphate (IP3) and ATP.

\section{Nicotinic acetylcholine receptor}

Distributed in both central and peripheral nervous systems, this ion channel is involved in synaptic transmission and signal transmission at neuro-muscular junction. It has a pentameric structure consisting of 5 subunits - $\alpha, \beta, \gamma, \delta$ arranged in varying ratios and a central ion conducting pore. Endogenous ligands include acetylcholine, choline and exogenous ones are nicotine and toxic alkaloid epibatidine obtained from poison dart frogs. ${ }^{3}$ The binding of the ligand induces conformational change and results in influx of cations like $\mathrm{Na}^{+}, \mathrm{K}^{+}$and $\mathrm{Ca}^{2+}$. In neurons, the $\mathrm{Ca}^{2+}$ influx induces release of neurotransmitters from synaptic vesicles. $\mathrm{N}_{\mathrm{M}}$ and $\mathrm{N}_{\mathrm{N}}$ are the two types of nicotinic acetylcholine receptor; $\mathrm{N}_{M}$ is located in the neuro-muscular junction while $\mathrm{N}_{\mathrm{N}}$ is located in neuronal synapses. Carbachol, a carbamate compound used in treatment of post-operative urine retention and succinylcholine commonly used as muscle relaxant for tracheal intubation acts as agonists at the $\mathrm{N}_{\mathrm{M}}$ receptor. $N_{M}$ receptor antagonists include $\alpha$-bungarotoxin found in Taiwanese krait and muscle relaxants used in surgical procedures like atracurium, pancuronium and tubocurarine. ${ }^{4} \mathrm{~N}_{\mathrm{N}}$ receptors are mainly located in the autonomic ganglia and antagonists at this channel includes mecamylamine, trimethaphan and hexamethonium, all drugs used in treatment of hypertension in the past.

\section{$G A B A_{A}$ receptor}

Primarily located in the brain, the GABA receptors are the target sites for the action of the major inhibitory neurotransmitter in the brain, i.e. GABA. GABA receptor is a ligand gated ion channel while $\mathrm{GABA}_{\mathrm{B}}$ is a metabotropic/G-protein coupled receptor. Similar to the nicotinic acetylcholine receptor, $\mathrm{GABA}_{\mathrm{A}}$ receptor also has a pentameric structure with 5 subunits. It functions for the conductance of chloride ion $\left(\mathrm{Cl}^{-}\right)$and this anion influx causes membrane hyperpolarization leading to inhibition of signal transmission. GABA is the endogenous agonist at $\mathrm{GABA}_{\mathrm{A}}$ receptor and bicuculline is a competitive anatagonist at the GABA binding site. Bicuculline is used only in research studies in epilepsy, as by inhibiting GABA, it causes neuronal excitation. The majority of clinically used drugs acting on the $\mathrm{GABA}_{\mathrm{A}}$ receptor bind to another allosteric site to exert its action (Figure 3). ${ }^{5}$ Positive allosteric regulators includes barbiturates and benzodiazepines used for their sedativehypnotic, anxiolytic, anticonvulsant and muscle relaxant properties; propofol and etomidate used as an induction agent in general anaesthesia; carisoprodol and meprobamate used as muscle relaxants in spastic 
conditions. $\mathrm{Cl}^{-}$conduction is facilitated by different mechanisms; barbiturates does this by prolonging the time the channel exists in open conformation while benzodiazepines enhances the frequency of opening of these channels. ${ }^{6}$ The newer non benzodiazepine class of hypnotics like zopiclone, zolpidem and zaleplon also act by allosteric regulation of the $\mathrm{GABA}_{\mathrm{A}}$ receptor. Flumazenil acts as a negative allosteric regulator and is used as an antidote in benzodiazepine toxicity.

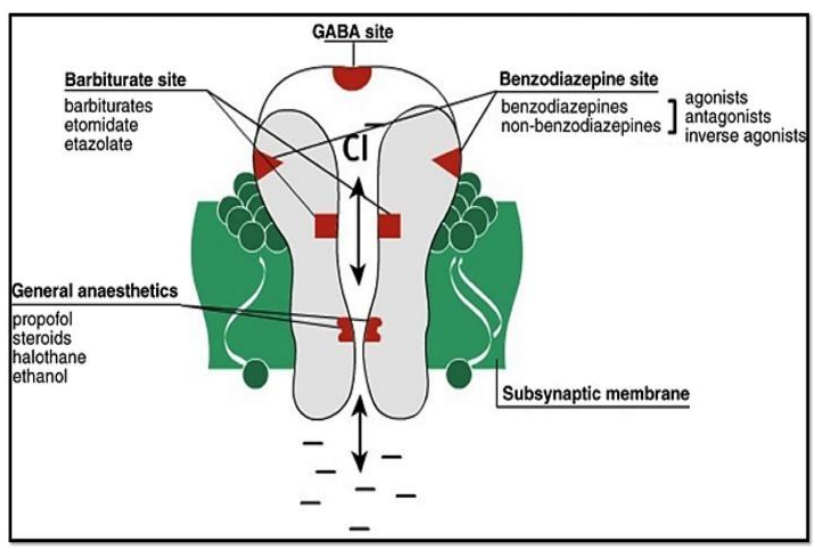

Figure 3: GABA-A receptor and ligand binding sites.

\section{5- $\mathrm{HT}_{3}$ receptor}

There exists 7 classes of 5 -HT receptors namely $5-\mathrm{HT}_{1}$ to $5-\mathrm{HT}_{7}$. All the 5-HT receptors with the exception of 5HT3 are metabotropic receptors. Being a ligand gated ion channel, the $5-\mathrm{HT}_{3}$ receptor structure closely resembles that of nicotinic acetylcholine receptor. It exists as a pentamer with a central pore that is selective to $\mathrm{Na}^{+}, \mathrm{K}^{+}$ and $\mathrm{Ca}^{2+}$. They are primarily distributed in CNS and also in the peripheral nervous system. In-vivo studies in rats have demonstrated $5-\mathrm{HT}_{3}$ receptors in neocortex, amygdala and hippocampus. In CNS, they are involved in the regulation of responses like nausea, vomiting, anxiety and mood. In the peripheral nervous system, they mediate neuronal excitability, gastrointestinal motility and emesis reflex. The antagonists of $5-\mathrm{HT}_{3}$ find application as antiemetics; the antiemetics ondansetron, palonasetron are used especially in treatment of cancer chemotherapy induced vomiting; the antiemetic metoclopramide although primarily acting as a D2 inhibitor also acts as 5$\mathrm{HT}_{3}$ antagonist. $^{7}$

\section{Glycine receptor}

Glycine is yet another inhibitory neurotransmitter in CNS along with GABA. The primary distribution of glycine receptors are in the brainstem and spinal cord where by mediating $\mathrm{Cl}^{-}$conductance they play an inhibitory role. The anion influx due to intracellular $\mathrm{Cl}^{-}$entry causes membrane hyperpolarization and terminates the signal transmission. Differential expression of the $\alpha$ and $\beta$ subunits results in various subtypes of the receptor. Endogenous agonists include amino acids glycine, alanine, taurine and serine. Antagonists include the toxic alkaloids strychnine and brucine found in Strychnos nuxvomica seeds. Glycine receptor inhibition by these toxins lead to exaggerated neuronal exciation that manifests as muscle spasms and convulsions seen in strychnine poisoning. Hyperekplexia is a rare genetic disorder occurring to reduced gene expression of the glycine receptor gene (GlyR) resulting in exaggerated response to stimulus and muscle rigidity. ${ }^{8}$

\section{Ionotropic glutamate receptor}

Glutamate and aspartate are the two major excitatory neurotransmitters in CNS and the primary distribution of glutamate receptors are in the brain. These receptors exhibit higher affinity for glutamate over aspartate. On the basis of affinity for ligands other than glutamate, the ionotropic glutamate receptors are classified into four subtypes namely AMPA, NMDA, Kainate and Delta receptor. ${ }^{9}$ The major two subtypes, i.e. AMPA and NMDA receptors will be discussed here.

\section{AMPA receptor}

These receptors exhibit higher affinity for $\alpha$-amino-3hydroxy-5-methyl-4-isoxazolepropionic acid (AMPA) over glutamate and is thus named after this ligand. It is distributed mainly in the brain where it is involved in synaptic plasticity and the process of Long Term Potentiation (LTP) of neuronal signals, which is the underlying mechanism in learning and memory. ${ }^{10}$ The AMPA receptor is a tetramer consisting of 4 subunits namely GluR1, GluR2, GluR3 and GluR4. The channel is non-selectively permeable to cations like $\mathrm{Na}^{+}, \mathrm{K}^{+}$and $\mathrm{Ca}^{2+}$. Cation influx into the cell induces membrane depolarization and leads to cell excitation and this function is implicated in excitotoxicity and epileptogenic potential on hyper activation of AMPA receptors. Agonists include AMPA and glutamate and kynurenic acid is the endogenous antagonist. Allosteric regulators are used in pharmacotherapy; positive allosteric agents includes piracetam, used in treatment of myoclonus and cyclothiazide, a diuretic used for treating hypertension in past. Negative allosteric regulators include perampanel, a US FDA approved anticonvulsant used in treatment of partial seizures and generalized tonic-clonic seizures. ${ }^{11}$

\section{NMDA receptor}

NMDA receptor is so named after its affinity for the synthetic compound N-Methyl-D-aspartate that mimicks the action of endogenous ligand, glutamate. The NMDA receptor exhibits equal affinity for two endogenous ligands - glutamate and glycine, where glutamate acts as agonist and glycine as co-agonist. The functioning of the channel is dependent on both ligand binding and also on membrane voltage; gating of the channel is regulated by ligand binding and the ion flow through an open state channel is dependent on membrane voltage. $\mathrm{Mg}^{2+}$ and $\mathrm{Zn}^{2+}$ acts as inhibitory regulators of the receptor by 
binding to extracellular sites on the receptor (Figure 4). ${ }^{12}$ Membrane depolarization expels the $\mathrm{Mg}^{2+}$ and $\mathrm{Zn}^{2+}$ and reactivates ion conductance through the channel. ${ }^{9}$ The NMDA receptor is a heterotetramer of two GluN1 and GluN2 subunits. Each subunit possess three domains namely the extracellular, transmembrane and cytoplasmic domains. The extracellular domain of GluN1 binds to glycine and GluN2 binds to glutamate; the transmembrane domain contains the central pore for ion flow and the cytoplasmic domain contains binding sites for regulation by kinases and phosphatases. Agonists at NMDA receptor include glutamate, aspartate, serine and cycloserine. NMDA is a partial agonist. Antagonists include the anaesthetic agents ketamine and nitrous oxide; memantine used in Alzheimer's disease; dextromethorphan used as an anti-tussive and the recreational drug phencyclidine/PCP. ${ }^{13}$ Phencyclidine induced NMDA antagonism underlies the glutamate hypothesis of schizophrenia and phencyclidine administered rats are used as animal models of schizophrenia. ${ }^{14}$ Other weak antagonists include the opioids tramadol and methadone and antiviral drug amantadine.

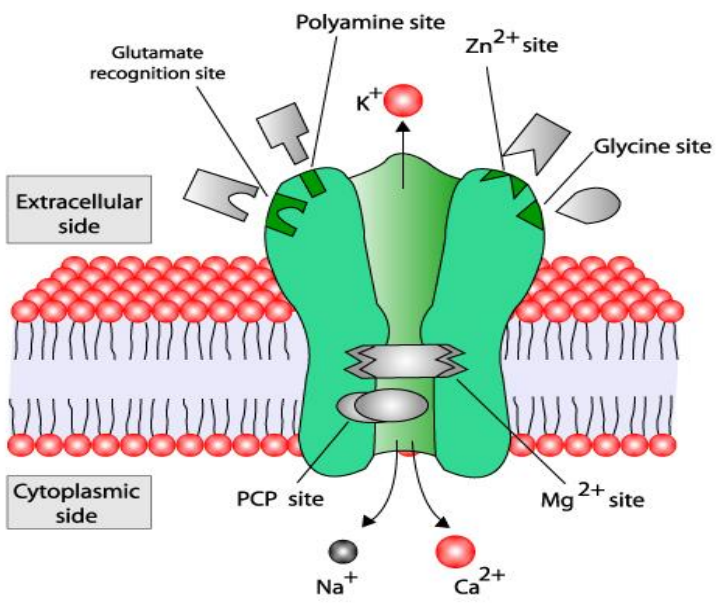

Figure 4: Schematic representation of the NMDA (N Merthyl D- Aspartate) receptor complex.

\section{Inositol triphosphate receptor}

The inositol triphosphate receptor or InsP3R is located intracellularly and distributed in almost all cell types. Located adjacent to the intracellular $\mathrm{Ca}^{2+}$ stores, the InsP3R is involved in the $\mathrm{Ca}^{2+}$ release from the stores. The receptor is regulated by two ligands that are second messengers; inositol-1,4,5 triphosphate and $\mathrm{Ca}^{2+}$. Activation of the phospholipase $\mathrm{C}$ causes hydrolysis of phosphatidylinositol 4,5 bisphosphate $\left(\mathrm{PIP}_{2}\right)$ producing inositol triphosphate $\left(\mathrm{IP}_{3}\right)$ and diacyl glycerol (DAG). IP3 being water soluble diffuses into the cytoplasm where it binds to the inositol triphosphate receptor and induces release of $\mathrm{Ca}^{2+}$ stores from the endoplasmic/sarcoplasmic reticulum. This process is termed as Calcium Induced Calcium Release (CICR). ${ }^{15}$ Agonists include the fungal products adenosphostins obtained from Penicillium brevicompactum and antagonists include the antimalarial drugs quinine, quinidine and chloroquine; immunosuppressant tacrolimus and anticoagulant heparin. ${ }^{16}$

\section{Epithelial sodium channels (ENaC)}

These channels are mainly distributed in the tight epithelia of distal convoluted tubule and collecting duct of nephrons in kidney. In the nephrons, they are involved in the $\mathrm{Na}^{+}$transport into the cell through the apical membrane (Figure 5). ${ }^{17}$ On the other hand, the intracellular $\mathrm{Na}^{+}$is pumped out into the ECF by $\mathrm{Na}^{+}-\mathrm{K}^{+}$ ATPase; these opposing mechanisms regulate the $\mathrm{Na}^{+}$ levels in the ECF and thus influence the ECF volume and blood pressure. ${ }^{17}$

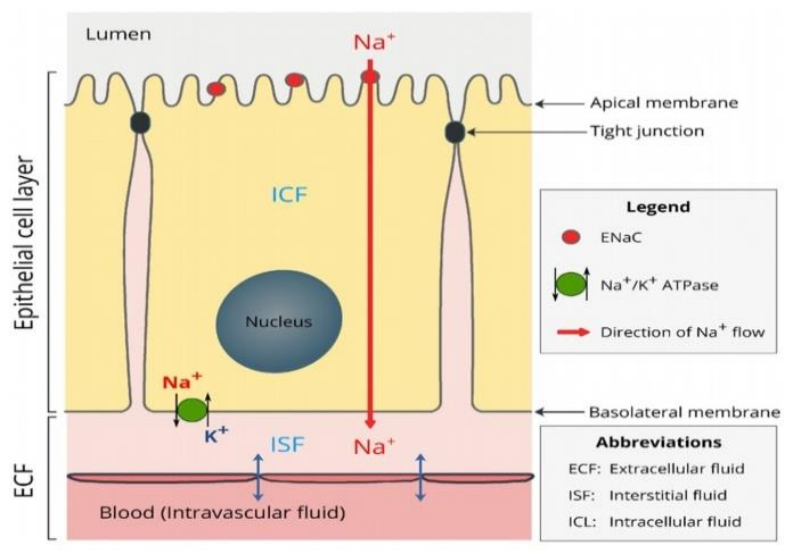

Figure 5: schematic illustration of the location and function of $\mathrm{ENaC}$ in epithelia.

The ENac has a heterotrimer structure composed of three homologous subunits of $\alpha, \beta, \gamma$ or $\delta$. Two types of transmembrane segments namely TM1 and TM2 forms triads in each subunit to form a total of 6 transmembrane segments; the central pore for ion flow is formed by the TM2 triad. Apart from the epithelia of collecting tubules in kidney, $\mathrm{ENaC}$ is also seen in cilia of multinucleated cells in bronchus, female reproductive tract, distal colon, salivary and sweat gland ducts. They are involved in $\mathrm{Na}^{+}$ homeostasis, epidermal differentiation, barrier functioning, lipid synthesis and secretion, keratinocyte migration and taste perception. Pseudohypoaldosteronism Type A is condition in which loss of function mutation of ENaC genes leads to renal salt wasting, hypovolemia and hypotension, metabolic acidosis, elevated levels of renin and aldosterone and frequent respiratory infections. In cystic fibrosis, in addition to reduced expression of $\mathrm{Cl}^{-}$ conducting channels, there is increased expression of $\mathrm{ENaC}$ in airway epithelia, leading to exaggerated $\mathrm{Na}^{+}$ reabsorption and drying up of secretions. Amiloride, a potassium sparing diuretic, acts as antagonist of these $\mathrm{ENaC}$ and is also used for nephrogenic diabetes insipidus especially lithium induced diabetes insipidus. Inhalational amiloride has also been tried in treatment of cystic fibrosis. ${ }^{18}$ 


\section{Purinergic P2X receptor}

Purinergic or purinoreceptors are involved in multiple cell signalling pathways like cell proliferation, cytokine secretion and apoptosis. The P1 type and P2Y, P2T and $\mathrm{P} 2 \mathrm{U}$ receptors are all metabotropic receptors while $\mathrm{P} 2 \mathrm{X}$ receptor is ligand gated ionotropic channel. Due to $\mathrm{Ca}^{2+}$ influx through open $\mathrm{P} 2 \mathrm{X}$ channels; these are involved in the initiation of muscle contraction in cardiac muscle, skeletal muscles and smooth muscles of urinary bladder, vas deferens and in vessels. Downstream activation of calcineurin and NFKB are involved in modifying the gene expression as in lymphocytes. The channel has a trimeric structure with three subunits surrounding the central pore. For activation, 3 ATP molecules bind to the three subunit interfaces. There are 7 subtypes of $\mathrm{P} 2 \mathrm{X}$ receptors $-\mathrm{P} 2 \mathrm{X} 1$ to $\mathrm{P} 2 \mathrm{X} 7$ and they can form heteromultimers like $\mathrm{P} 2 \mathrm{X} 2 / \mathrm{P} 2 \mathrm{X} 3$ and $\mathrm{P} 2 \mathrm{X} 4 / \mathrm{X} 6$. Extracellular ATP is the endogenous agonist at $\mathrm{P} 2 \mathrm{X}$ receptor. Antagonists includes suramin used in treatment of trypanosomiasis and investigational agents acting at $\mathrm{P} 2 \mathrm{X} 1$ receptor (in thrombosis); at $\mathrm{P} 2 \mathrm{X} 3, \mathrm{P} 2 \mathrm{X} 4$ and $\mathrm{P} 2 \mathrm{X} 7$ (in neuropathic pain); at $\mathrm{P} 2 \mathrm{X} 1, \mathrm{P} 2 \mathrm{X} 3$ and $\mathrm{P} 2 \mathrm{X} 2 / \mathrm{X} 3$ (in dysfunctional urinary bladder); at $\mathrm{P} 2 \mathrm{X} 7$ (in rheumatoid arthritis, osteoarthritis and depression). ${ }^{19}$

\section{ATP-sensitive K+ channels $\left(K_{A T P}\right)$}

These channels exhibit affinity for intracellular ATP. ATP inhibits these channels by reducing the duration of open state of the channels. It has an octamer structure with two types of subunits; the inward rectifying potassium channel (Kir6) subunits and sulfonylurea (SUR) subunits (Figure 6). ${ }^{20}$ The central pore is formed by Kir6 subunits and the SUR act as regulatory subunits. Nearly all pharmacological agents acting on ATPsensitive $\mathrm{K}^{+}$channels act at the SUR site. A $\mathrm{K}_{\mathrm{ATP}}$ channel openers (KCO) includes diazoxide used in treatment of insulinoma; minoxidil used in hypertension and alopecia; nicorandil and pinacidil used in angina (nitrate tolerant patients) and hypertension respectively. $\mathrm{K}_{\mathrm{ATP}}$ blockers like the sulfonylurea class of drugs (glibenclamide, glimepiride) and meglitinides (repaglinide, nateglinide) find application as insulin secretagogues in treatment of diabetes mellitus; as they block the $\mathrm{K}_{\mathrm{ATP}}$ channel in pancreatic $\beta$ cells leading to intracellular $\mathrm{K}^{+}$accumulation and insulin release. ${ }^{20}$

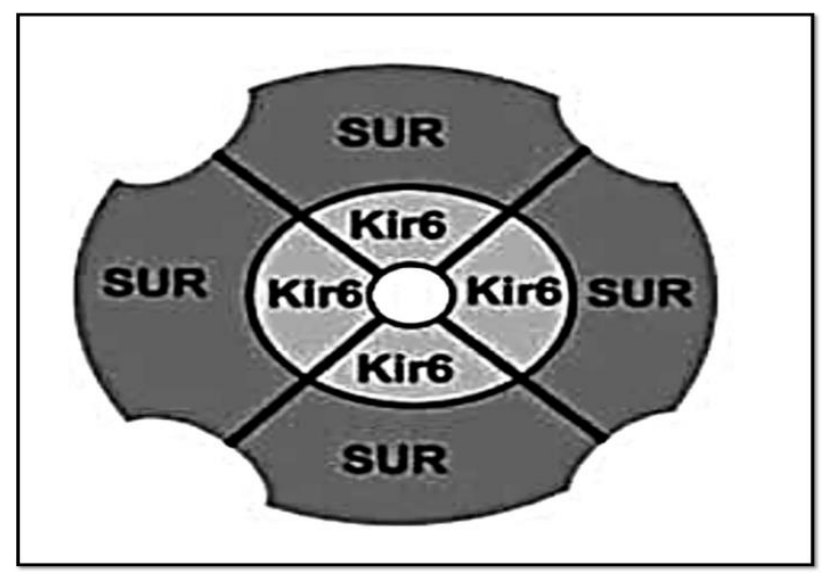

Figure 6: Structure of K-ATP channel.

Table 1: Tissue distribution, functions of $K_{\mathrm{ATP}}$ channels and therapeutic uses of $K_{\mathrm{ATP}}$ channel openers and blockers.

\begin{tabular}{|ll|ll|}
\hline Tissue & Functions & Therapeutic uses & \\
\hline Pancreatic $\beta$ cell & Closure causes insulin secretion & Hypoglycemia, insulinoma & Type 2 diabetes mellitus \\
\hline Cardiac muscle & $\begin{array}{l}\text { Cardio protection, response to } \\
\text { stress }\end{array}$ & $\begin{array}{l}\text { Angina, cardio protection } \\
\text { during surgery/angioplasty }\end{array}$ & - \\
\hline Vascular smooth muscle & Vasodilation, resting blood flow & Angina, hypertension & - \\
\hline Hair follicles & Hair growth & Alopecia & - \\
\hline
\end{tabular}

Table 2: Types of calcium channels based on inhibitor sensitivity.

\begin{tabular}{|ll|lll|}
\hline Type & Dihydropyridine & $\boldsymbol{\omega}$ - conotoxin & $\boldsymbol{\omega}$ - agatoxin & Mibefradil \\
\hline L type & Blocked & Resistant & Resistant & Resistant \\
\hline N type & Resistant & Blocked & Resistant & Resistant \\
\hline P/Q type & Resistant & Resistant & Blocked & Resistnant \\
\hline R type & Resistant & Resistant & Resistant & Resistant \\
\hline T type & Resistant & Resistant & Resistant & Blocked \\
\hline
\end{tabular}

\section{VOLTAGE GATED ION CHANNELS}

In contrast with ligand gated ion channels, voltages gated ion channels exhibit higher selectivity for the ions and also open and close at faster rate and remain in one state 
for shorter duration. There are no molecules involved in the gating mechanism, rather the difference in membrane potential caused by ion migration induces a structural change in the channel and opens up the channel
(Figure 7). The voltage gated ion channels are usually activated by membrane depolarization (cation influx) and less frequently by membrane hyperpolarization (anion influx). ${ }^{21,22}$

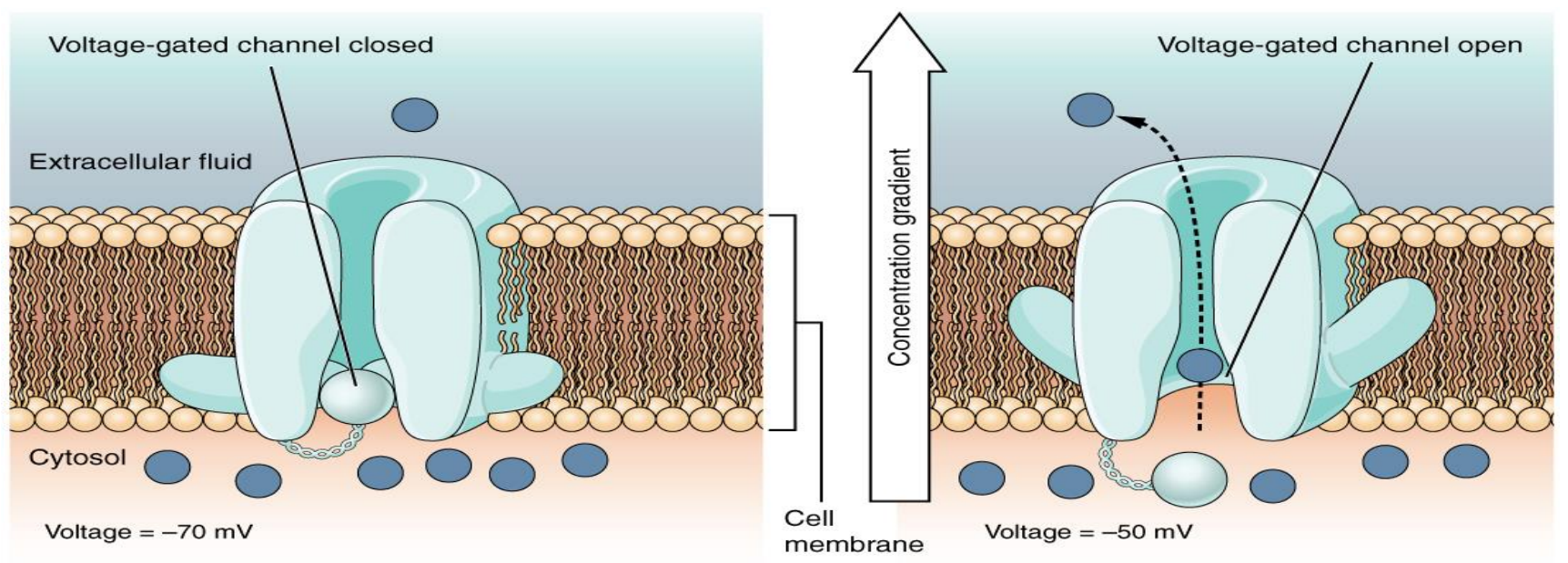

Figure 7: Mechanism of voltage gated ion channels.

\section{Voltage gated sodium channels}

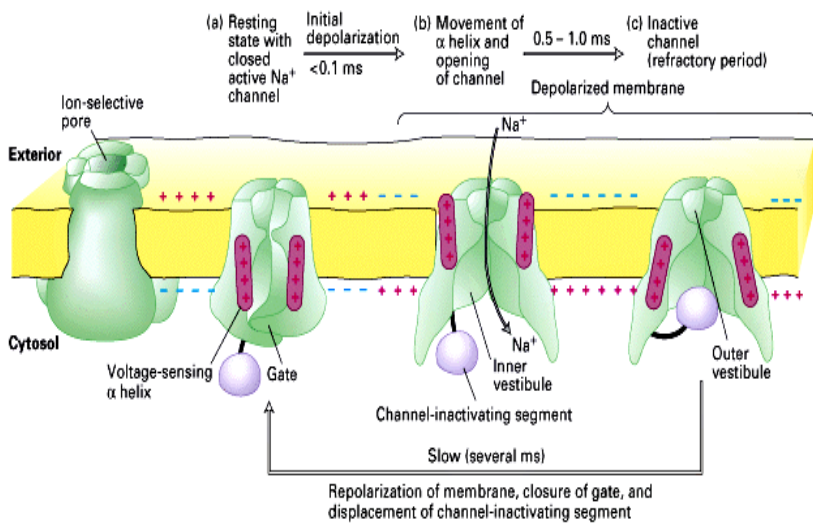

Figure 8: Voltage gated sodium channels and action potential generation.

Located mainly in excitable tissues like nerve and muscle, voltage gated sodium channels are involved in the action potential generation central to signal transmission. The channel has a trimeric structure with a pore forming $\alpha$ subunit and two regulatory $\beta$ subunits. The $\alpha$ subunit has 4 domains, each consisting of 6 transmembrane segments (S1-S6). The S4 helix contains charged amino acids and acts as the voltage sensor. The inhibitors of voltage gated sodium channels are used in various conditions; lignocaine and tetracaine used as local anaesthetics block the central pore and inhibit ion flow and action potential generation (Figure 8). Class I antiarrhythmics like quinidine, mexiletene and flecainide are $\mathrm{Na}^{+}$channel inhibitors and inhibit the cardiac action potential generation. The commonly used antiepileptic drugs phenytoin, carbamazepine and phenobarbitone act as $\mathrm{Na}^{+}$channel inhibitors. Valproates also act at $\mathrm{Na}^{+}$ channel although it has multiple mechanisms of action. The marine toxins saxitoxin, seen in dinoflagellates and tetrodotoxin, seen in puffer fish are also $\mathrm{Na}^{+}$channel blockers; they cause muscle and respiratory paralysis. ${ }^{24}$

\section{Voltage gated calcium channels}

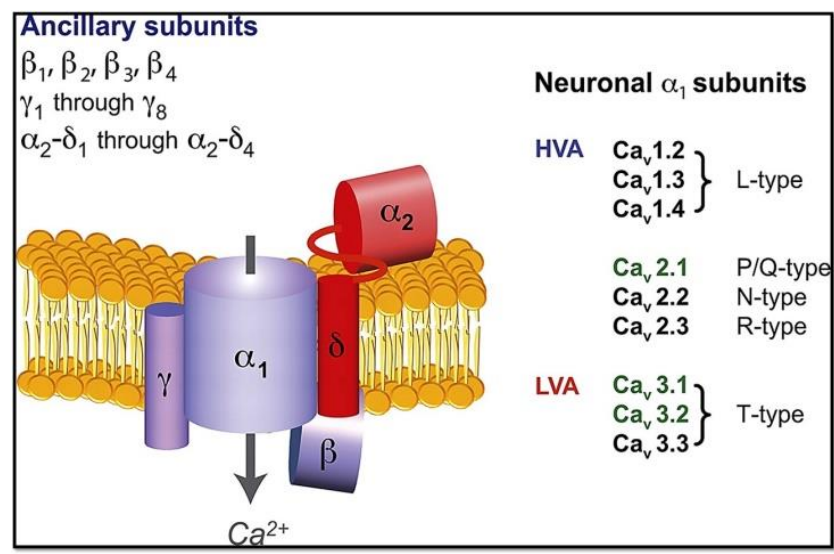

Figure 9: Voltage gated calcium channel with subunits and types.

They are distributed mainly in neurons, myocytes, glial cells and zona glomerulosa of adrenal gland. Similar to voltage gated sodium channels, these channels are also activated by membrane depolarization and it is selectively permeable to $\mathrm{Ca}^{2+}$. On the basis of inhibition 
ofthese channels, voltage gated $\mathrm{Ca}^{2+}$ channels are classified into four types - L, N, P/Q and R type. The channels inhibited by dihydropyridines like nifedipine, amlodipine are L-type; those inhibited by the cone snail toxin $\omega$-conotoxin are $\mathrm{N}$-type and channels sensitive to $\omega$-agatoxin found in spider venom are $\mathrm{P} / \mathrm{Q}$-type. The $\mathrm{R}$ type is resistant to all the abovementioned inhibitors. The channel consists of a combination of different subunits like $\alpha 1, \beta 1-4, \gamma 1-8$ and $\alpha 2-\delta 1$ to $\alpha 2-\delta 4$. The $\alpha 1$ is the central main subunit containing the pore for ion flow, the rest are regulatory subunits (Figure 9 ). ${ }^{25}$

Dihydropyridines which includes drugs like nifedipine, amlodipine and nimodipine are inhibitors of L-type and T-type $\mathrm{Ca}^{2+}$ current. Verapamil, a phenylalkylamine and diltiazem, a benzothiazepine are inhibitors of L-type $\mathrm{Ca}^{2+}$ current alone. All three classes of drugs are used in treatment of hypertension and angina. Verapamil and diltiazem are also used as antiarrhythmics (class IV). Ziconotide administered intrathecally is used as analgesic in cases refractory to opioid analgesics. It is derived from the $\mathrm{N}$-type $\mathrm{Ca}^{2+}$ channel inhibitor $\omega$-conotoxin found in cone snails. Gabapentin and pregabalin are drugs used in neuropathic pain; they act by inhibiting the $\alpha 2-\delta$ subunit. $^{26,27}$

\section{Voltage gated potassium channels (KV)}

With 78 members, potassium channels are the most abundant subfamily among the ion channels. Based on the transmembrane segments and mode of activation, they are broadly classified into 4 types:

i. Inwardly rectifying $2 \mathrm{TM} \mathrm{K}^{+}$channels

ii. Two pore $4 \mathrm{TM} \mathrm{K}^{+}$channels

iii. Calcium activated $6 \mathrm{TM} \mathrm{K}^{+}$channels

iv. Voltage gated $6 \mathrm{TM} \mathrm{K}^{+}$channels

Voltage gated potassium channels are typically composed of tetramer of identical $\alpha$ subunits, forming the pore in centre. Other subunits only play ancillary role in channel function. Each subunit is further composed of 6 transmembrane segments numbered S1-S6. The central pore lies between S5 and S6 segments. The S4 helix containing positively charged arginine residues acts as the voltage sensor (Figure 10). ${ }^{24}$ There exist 12 subtypes of voltage gated potassium channels from Kv1-Kv12 classified according to the different $\alpha$ subunit types. ${ }^{28}$

Opening of $\mathrm{KV}$ channel causes $\mathrm{K}^{+}$efflux leading to membrane repolarization and hyperpolarization. As the activation of $\mathrm{KV}$ channel results in inhibition of signal transmission, $\mathrm{KV}$ blockers find application in various clinical conditions. $\mathrm{KV}$ channels have a role in $\mathrm{Ca}^{2+}$ signalling, cell volume regulation and cell secretory function. By mediating cell proliferation and migration, $\mathrm{KV}$ channels are important in tumour growth and proliferation. KV channel blockers are potential candidates in cancer chemotherapy. Agents that act as $\mathrm{KV}$ channel blockers are of 3 groups: metal ions, organic small molecules and venom related peptides. These agents can be used to block the channel internally like dtubocurarine and verapamil or externally at the outer vestibule like toxins from scorpion, sea snake and cone snail venom. Others act at the voltage sensor domain and modify gating mechanism like the spider venom toxin hanatoxin. An additional area of clinical application is the use of KV channel antibodies to inhibit the channel. ${ }^{2}$

\section{Voltage-gated K ${ }^{+}$channel (tetramer)}

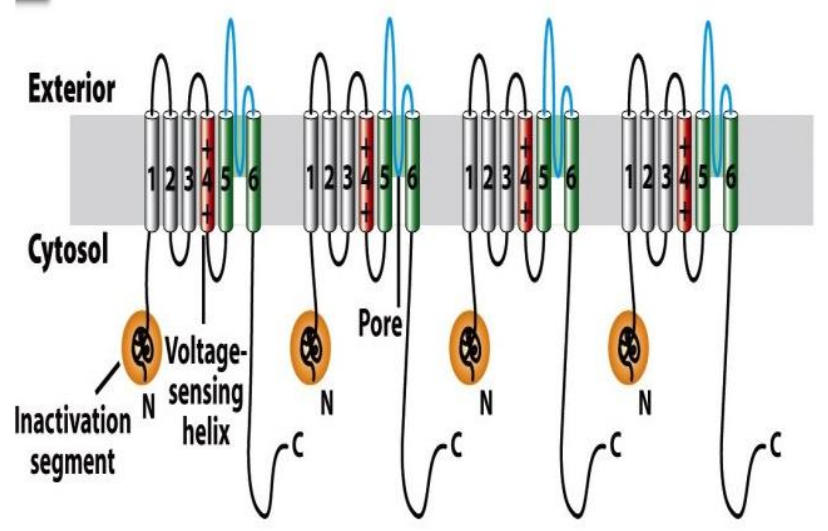

Figure 10: Voltage gated potassium channel.

\section{Ryanodine receptor}

They are basically intracellular channels regulating calcium signalling. The channel derives its name from its affinity for the plant alkaloid ryanodine. There exists three isoforms of the ryanodine receptor: RyR1, RyR2 and RyR3 distributed in the skeletal muscle, myocardium and brain respectively. In skeletal muscles, the ryanodine receptor is coupled with the dihydropyridine receptor which is an L-type $\mathrm{Ca}^{2+}$ channel and is involved in the excitation-contraction coupling mechanism. In smooth muscles of the myocardium, $\mathrm{Ca}^{2+}$ influx through voltage gated $\mathrm{Ca}^{2+}$ channels activates the ryanodine receptor to release further $\mathrm{Ca}^{2+}$ from the stores in sarcoplasmic reticulum. This mechanism is called as Calcium Induced Calcium Release (CICR). Agonists at ryanodine receptor include the endogenous agonist cyclic ADP ribose and other agents include caffeine and the anti-trypanosomal drug suramin. In a rare autosomal dominant disorder called malignant hyperthermia $(\mathrm{MH})$, there is increased activity of the ryanodine receptor due to RYR1 gene mutation. Such individuals develop features of metabolic acidosis, muscle rigidity, hyperthermia and tachycardia on administration of certain drugs like the muscle relaxant succinylcholine and anaesthetic halothane. The antidote for this is the drug dantrolene that acts as an antagonist at the ryanodine receptor. ${ }^{30}$ 
Table 3: Types of voltage gated $\mathrm{K}+$ channels with their function and pharmacological agents acting on them.

\begin{tabular}{|c|c|c|c|c|c|c|c|c|}
\hline \multicolumn{2}{|c|}{$\begin{array}{l}\text { Channel } \\
\text { type }\end{array}$} & \multicolumn{2}{|c|}{ Distribution } & \multicolumn{2}{|l|}{ Function } & \multicolumn{2}{|c|}{$\begin{array}{l}\text { Action of pharmacological } \\
\text { agents (blockers) }\end{array}$} & Other features \\
\hline \multicolumn{2}{|c|}{$\begin{array}{ll}\mathrm{Kv} & 1.1 \\
\mathrm{Kv} & 1.2\end{array}$} & \multicolumn{2}{|c|}{$\begin{array}{l}\text { CNS } \\
\text { Heart } \\
\text { Vasculature } \\
\text { Immune system }\end{array}$} & \multicolumn{2}{|c|}{$\begin{array}{l}\text { Inhibits neuronal } \\
\text { excitation }\end{array}$} & \multicolumn{2}{|c|}{$\begin{array}{l}\text { 4-aminopyridine is } \mathrm{Kv} \text { blocker, } \\
\text { improves nerve conduction. } \\
\text { Fampridine used in multiple } \\
\text { sclerosis, improves walking ability }\end{array}$} & $\begin{array}{l}\text { Kv } 1.1 \text { loss of function } \\
\text { mutation- autosomal } \\
\text { dominant hypomagnesemia } \\
\text { temporal lobe epilepsy }\end{array}$ \\
\hline \multicolumn{2}{|c|}{ Kv 1.3} & \multicolumn{2}{|l|}{$\mathrm{T}$ cells } & \multicolumn{2}{|c|}{$\begin{array}{l}\text { Tcell activation, } \\
\text { proliferation and } \\
\text { cytokine } \\
\text { production }\end{array}$} & \multicolumn{2}{|c|}{$\begin{array}{l}\text { Margatoxin - immunosuppressant } \\
\text { Psoralen PAP-I effective in rat } \\
\text { allergic contact dermatitis } \\
\text { Clofazimine - prevent foreskin } \\
\text { transplant rejection in mice }\end{array}$} & $\begin{array}{l}\text { Gene deletion - reduction } \\
\text { of adipose tissue } \\
\text { deposition, improves } \\
\text { insulin sensitivity }\end{array}$ \\
\hline \multicolumn{2}{|c|}{ Kv 1.5} & \multicolumn{2}{|c|}{ Atrial muscle } & \multicolumn{2}{|c|}{$\begin{array}{l}\text { Primary } \\
\text { component of } \\
\text { ultra rapid } \\
\text { delayed rectifier } \\
\text { atrial AP } \\
\text { repolarization }\end{array}$} & \multicolumn{2}{|c|}{$\begin{array}{l}\text { Vernakalant - multiple channel } \\
\text { blocker including Kv } 1.5\end{array}$} & $\begin{array}{l}\text { Target for treatment of } \\
\text { atrial fibrillation }\end{array}$ \\
\hline \multicolumn{2}{|c|}{ Kv 2.1} & \multicolumn{2}{|c|}{$\begin{array}{l}\text { Pancreatic } \beta \text { cells } \\
\text { CNS neurons }\end{array}$} & \multicolumn{2}{|c|}{$\begin{array}{l}\text { Neuronal } \\
\text { repolarization }\end{array}$} & \multicolumn{2}{|c|}{ Increases insulin secretion } & - \\
\hline \multicolumn{2}{|c|}{ Kv 3.4} & \multicolumn{2}{|c|}{ CNS neurons } & \multicolumn{2}{|l|}{ Inactivation } & \multicolumn{2}{|c|}{$\begin{array}{l}\text { Neuroprotective role - Tried in } \\
\text { Alzheimer's disease }\end{array}$} & $\begin{array}{l}\mathrm{K}+\text { depletion by channel } \\
\text { hyperactivity causes } \\
\text { neuronal cell death }\end{array}$ \\
\hline $\begin{array}{l}\mathrm{Kv} \\
4.2 \\
\mathrm{Kv} \\
4.3\end{array}$ & $\begin{array}{l}\text { Bra } \\
\text { dor } \\
\text { neu } \\
\text { spil }\end{array}$ & $\begin{array}{l}\text { heart and } \\
\text { horn } \\
\text { is in } \\
\text { cord }\end{array}$ & \multicolumn{2}{|c|}{$\begin{array}{l}\text { Modulation of pain } \\
\text { plasticity in dorsal } \\
\text { horn neurons }\end{array}$} & \multicolumn{2}{|c|}{$\begin{array}{l}\text { Kv } 4.2 \text { activators - } \\
\text { analgesic action }\end{array}$} & - & \\
\hline $\begin{array}{l}\mathrm{Kv} \\
7.1\end{array}$ & $\begin{array}{l}\text { Hec } \\
\text { ear, } \\
\text { tiss } \\
\text { kid }\end{array}$ & $\begin{array}{l}\text { inner } \\
\text { ithelial } \\
\text { of lung, } \\
\text { and GIT }\end{array}$ & \multicolumn{2}{|c|}{$\begin{array}{l}\text { Slow delayed } \\
\text { rectifying current, } \\
\text { neuronal } \\
\text { repolarization }\end{array}$} & \multicolumn{2}{|c|}{$\begin{array}{l}\text { Amiodarone - class III } \\
\text { anti-arrhythmic }\end{array}$} & - & \\
\hline $\begin{array}{l}\mathrm{Kv} \\
7.2- \\
7.5\end{array}$ & $\mathrm{CN}$ & eurons & \multicolumn{2}{|c|}{$\begin{array}{l}\text { Regulates synaptic } \\
\text { plasticity and } \\
\text { neuronal excitability } \\
\text { in brain } \\
\text { Neuronal } \mathrm{K}+ \\
\text { conductance - M } \\
\text { current }\end{array}$} & \multicolumn{2}{|c|}{$\begin{array}{l}\text { Retigabine }- \text { FDA } \\
\text { approved anticonvulsant } \\
\text { Flupirtine - chemical } \\
\text { analog of Retigabine, } \\
\text { analgesic action in rat } \\
\text { models of neuropathic pain }\end{array}$} & \multicolumn{2}{|c|}{$\begin{array}{l}\text { *Effective analgesic action in diabetic } \\
\text { neuropathy and other pain models } \\
\text { *Neuropsychiatric disorders - anxiety, } \\
\text { ADHD, mania, bipolar disease and } \\
\text { schizophrenia }\end{array}$} \\
\hline $\begin{array}{l}\mathrm{Kv} \\
10.1\end{array}$ & $\begin{array}{l}\text { My } \\
\text { Tur }\end{array}$ & $\begin{array}{l}\text { lasts } \\
\text { ur cells }\end{array}$ & \multicolumn{2}{|c|}{$\begin{array}{l}\text { Confers increased } \\
\text { vascularity and } \\
\text { hypoxic resistance } \\
\text { to tumour cells }\end{array}$} & \multicolumn{2}{|c|}{$\begin{array}{l}\text { Astemizole and imipramine } \\
\text { In vitro studies - anti } \\
\text { proliferative action in } \\
\text { tumour cells } \\
\text { Mouse models- inhibitory } \\
\text { action in melanoma and } \\
\text { lung cancer metastasis }\end{array}$} & \multicolumn{2}{|c|}{$\begin{array}{l}70 \% \text { tumour cell lines in colon cancer } \\
\text { express Kv } 10.1\end{array}$} \\
\hline $\begin{array}{l}\mathrm{Kv} \\
11.1\end{array}$ & Car & c muscle & $\begin{array}{l}\text { Activa } \\
\text { depola } \\
\text { of card } \\
\text { potenti } \\
\text { Respor } \\
\text { cardiac } \\
\text { repolar }\end{array}$ & $\begin{array}{l}\text { d during } \\
\text { zation phase } \\
\text { ac action } \\
\text { l. } \\
\text { ible for } \\
\text { myocyte } \\
\text { zation }\end{array}$ & & $\begin{array}{l}\text { jit tumour cell } \\
\text { feration }\end{array}$ & $\begin{array}{l}\text { *Mutation } \\
\text { syndrome, } \\
\text { torsades de } \\
\text { *Overexpr } \\
\text { neurons - s }\end{array}$ & $\begin{array}{l}\text { in Kv } 11.1 \text { - long QT } \\
\text { entricular fibrillation and } \\
\text { pointes. } \\
\text { ssion in cultured cortical } \\
\text { hizophrenia model }\end{array}$ \\
\hline
\end{tabular}

Transient Receptor Potential channels (TRP)
These channels were initially studied in Drosophila (fruit flies) where they are involved in depolarization of photoreceptor cells and are essential in normal vision. It 
comprises of 28 subtypes spread across 7 subfamilies: TRPC (canonical), TRPV (vanilloid), TRPA (ankyrin), TRPM (melastatin), TRPP (polycystin), TRPML (mucolipin) and TRPN (no mechanoreceptor potential). TRP channels are non-selectively permeable to cations like $\mathrm{Na}^{+}, \mathrm{K}^{+}$and $\mathrm{Ca}^{2+}$. The structural studies on TRP channels are limited, available studies indicate at 6 transmembrane segmented structures similar to other voltage gated ion channels. Being widely distributed in different cell types, TRP channels are involved in multiple functions like modulation of pain, temperature, taste, pressure, vision, calcium and magnesium transport. Thermosensitive TRP channels regulate the action potential in somatosensory nociceptors. Overexpression of TRP channels are being studied in cardiac disorders like cardiomyopathies, cardiac fibrosis and cardiac remodelling. TRP channels are also involved in insulin secretion in pancreatic $\beta$ cells; modifiers of TRP channels may play a role in type 2 diabetes mellitus treatment. TRPM single nucleotide polymorphisms have been associated with phenotypes predisposed to type 2 diabetes mellitus. The TRP channels include members that exhibit both pro-proliferative and pro-apoptotic roles. Among the pro-proliferative types, TRPV6 expression is found to be elevated in carcinomas of colon, thyroid gland, ovary, breast, prostate and also in chronic myelogenous leukemia. TRPC1 plays a dual role; in normal tissues it exhibits pro-proliferative role but in tumour cells it favoured apoptotic mechanisms. TRPM1 levels are suppressed in malignant melanoma cells. The studies on TRP channels are limited so further research into the structure and functions of the TRP channels might prove beneficial in opening up new avenues for therapeutic targets. ${ }^{31}$

\section{CatSper channels}

CatSper stands for Cation channels of Sperm. CatSper channels are primarily located in the principal piece of spermatozoa tail and also in the testis. They exist as tetramer of four $\alpha$ subunits, with the central pore formed by the $\alpha$ subunits and $\beta, \gamma$ and $\delta$ acting as ancillary regulatory subunits. Each subunit is further made up of 6 transmembrane segments resembling other voltage gated ion channels. CatSper mainly acts as calcium influx channels and promotes the flagellar motility of the spermatozoa. Inhibition of CatSper genes inhibits flagellar motion of the spermatozoa and penetration of the egg cumulus and zona pellucida. In human ejaculated spermatozoa, the progesterone $(<50 \mathrm{nM})$ promotes CatSper activity and thus improves sperm motility in the female reproductive tract. Based on the different types of $\alpha$ subunit present, the CatSper channels are of 4 types CatSper 1-4.

\section{Cyclic Nucleotide Gated channels (CNG)}

CNG channels are a group of ion channels that includes two subgroups: the cyclic nucleotide gated channels, gated by intracellular ligands like cyclic AMP or cyclic
GMP and the other subgroup being hyperpolarization activated channels $(\mathrm{HCN})$. The structure resembles other voltage gated ion channels with four subunits encircling the central pore and each subunit further composed of 6 transmembrane segments. The $\mathrm{CNG}$ channels were initially studied in the retinal photoreceptor cells. These channels are primarily involved in vision and olfactory functioning and other sites of distribution include the brain, heart, kidney and gonads. The CNG channels are further classified based on subunit properties into CNGA1, CNGA2, CNGA3 and CNGA4; the HCN channels are classified into HCN1, HCN2, HCN3 and HCN4. CNGA1, CNGB1 are distributed in the retinal rod cells; CNGA3, CNGB3 are located in retinal cone cells and CNGA2, CNGA4 are located in olfactory receptor cells. In most sites, $\mathrm{CNG}$ channels act as $\mathrm{Ca}^{2+}$ influx channels causing membrane depolarization like in olfactory receptors and also in spermatozoa. By inducing $\mathrm{Ca}^{2+}$ entry, it promotes sperm motility and acrosomal exocytosis (fusion of sperm and egg). HCN channels are located in the sinoatrial node which is the pacemaker of the heart; where membrane hyperpolarization activates the channels and maintains the cardiac rhythm. The current through HCN channels are termed as 'funny current'/If. The drug ivabradine acts as HCN channel blocker and inhibitor of the If current and is used in treatment of heart failure. ${ }^{33}$

\section{Voltage gated proton channels}

These channels exhibit dual regulation by both membrane voltage and also local $\mathrm{pH}^{+}$. They are activated with membrane depolarization but the response is further dependent on $\mathrm{pH}^{+}$. The main function of these channels is to act as proton efflux channels, i.e. for acid extrusion, so as to balance the electron flow across cell membranes. They are distributed in wide variety of tissues like lung, prostate, kidney, myocytes, T cells, B cells, monocytes, granulocytes and microglia. In phagocytes, these channels are involved in the respiratory burst reaction. In respiratory burst reaction, NADPH oxidase induces membrane depolarization by promoting electron influx and the proton channels extrude $\mathrm{H}^{+}$to prevent acidic environment inside the phagocytes. The structure and the pharmacological agents acting on these channels are still under study and further research in this field is needed. ${ }^{34}$

\section{SUMMARY}

Drug discovery is an elaborate and long process that requires countless trial and error attempts to finally arrive at a promising molecule. Identifying a target and attempting to develop a molecule that acts specifically on the target or the pathways involving the target forms the stage of target identification and validity of drug discovery. In retrospect, the thousands of approved drugs act at a limited number of targets with the ion channels being the 2 nd most common drug target. The study of the structure and intricate mechanisms of ion channel function becomes imperative for a better shot at drug 
designing. Ion channels function to conduct ions across cell membranes and the regulatory mechanism called gating offers a wide area for research into developing new chemical entities. The extracellular and intracellular ligands offer multiple drug targets as in ligand gated ion channels and altering the membrane voltage or local $\mathrm{pH}^{+}$ are methods of drug designing in voltage gated ion channels. Another feature of the ion channels is the multiple domains/ binding sites, each of which can be selectively developed for drug targeting. Newer technology like the High Throughput Screening methods employed in the pharmaceutical industry has made it feasible to screen thousands of candidate molecules for desired action at desired drug targets. The on going research into relatively newer channels like CatSper, $\mathrm{CNG}, \mathrm{HCN}$ and voltage gated proton channels will shed new light into cellular mechanisms and in future offer us newer drug targets for design and development.

Funding: No funding sources

Conflict of interest: No

Ethical approval: Not required

\section{REFERENCES}

1. Overington JP, Lazikani BA, Hopkins AL. How many drug targets are there? Nat Rev Drug Discov. 2006;5:993-6.

2. Kornreich BG. The patch clamp technique: Principles and technical considerations. J Vet Cardiol. 2007;9:25-37.

3. Wonnacott S. Presynaptic nicotinic ACh receptors. Trends Neurosci. 1997;20:92-8.

4. Samson AO, Levitt M. Inhibition mechanism of the acetylcholine receptor by alpha-neurotoxins as revealed by normal-mode dynamics. Biochemistry. 2008;47:4065-70

5. Benzodiazepine and psychotics. Georgetown University school of Medicine. 2016 [cited 2016 Nov 19]

Available fromhttps://www.studyblue.com/notes/note/n/benzod iazepine-psychotics/deck/9685444.

6. Johnston GA. GABAA receptor pharmacology. Pharmacol Ther. 1996;69:173-98.

7. Niesler B. 5-HT(3) receptors: potential of individual isoforms for personalised therapy. Curr Opin Pharmacol. 2011;11:81-6.

8. Lynch JW. Molecular structure and function of the glycine receptor chloride channel. Physiol Rev. 2004;84:1051-95.

9. Dingledine R, Borges K, Bowie D, Traynelis SF. The glutamate receptor ion channels. Pharmacol Rev. 1999;51:7-61.

10. Whitlock JR, Heynen AJ, Shuler MG, Bear MF. Learning induces long-term potentiation in the hippocampus. Science. 2006;313:1093-7.

11. Rogawski MA. Revisiting AMPA receptors as an antiepileptic drug target. Epilepsy Curr. 2011;11:5663.
12. Schematic diagram of NMDA receptor complex. Anaesthesia UK. 2016 [cited 2016 Nov 19] Available from http://www.frca.co.uk/article.aspx?articleid=100515.

13. Paoletti P, Neyton J. NMDA receptor subunits: function and pharmacology. Curr Opin Pharmacol. 2007;7:39-47.

14. Reynolds LM, Cochran SM, Morris BJ, Pratt JA, Reynolds GP. Chronic phencyclidine administration induces schizophrenia-like changes in Nacetylaspartate and $\mathrm{N}$-acetylaspartylglutamate in rat brain. Schizophr Res. 2005;73:147-52.

15. Mikoshiba K. IP3 receptor/ $/ \mathrm{Ca}^{2+}$ channel: from discovery to new signaling concepts. J Neurochem. 2007;102:1426-46.

16. Bultynck G, Sienaert I, Parys JB, et al. Pharmacology of inositol trisphosphate receptors. Eur J Physiol. 2003;445:629-42.

17. Hanukoglu I, Hanukoglu A. Epithelial sodium channel (ENaC) family: Phylogeny, structurefunction, tissue distribution, and associated inherited diseases. Gene. 2016;579:95-132.

18. Boscardin E, Alijevic O, Hummler E, Frateschi S, Kellenberger $\mathrm{S}$. The function and regulation of acidsensing ion channels (ASICs) and the epithelial $\mathrm{Na}(+)$ channel $(\mathrm{ENaC})$ : IUPHAR Review 19. Br J Pharmacol. 2016;173:2671-701.

19. Syed NH, Kennedy C. Pharmacology of P2X receptors. WIREs Membr Transp Signal. 2012;1:1630.

20. Rodrigo GC, Standen NB. ATP-sensitive potassium channels. Curr Pharm Des. 2005;11:1915-40.

21. Triggle DJ. The pharmacology of ion channels: with particular reference to voltage-gated $\mathrm{Ca}^{2+}$ channels. Eur J Pharmacol. 1999;375:311-25.

22. Mechanism of voltage gated ion channels. 2016 [cited 2016 Nov 19] Available from https://cnx.org/contents/FPtK1zmh@8.25:fEI3C8Ot @ 10/Preface.

23. Yu FH, Catterall WA. Overview of the voltage-gated sodium channel family. Genome Biol. 2003;4:207.

24. Lodish H, Berk A, Matsudaira P. Molecular Cell Biology. $6^{\text {th }}$ edition. 2008.

25. Dunlap K, Luebke JI, Turner TJ. Exocytotic $\mathrm{Ca}^{2+}$ channels in mammalian central neurons. Trends Neurosci. 1995;18:89-98.

26. Khosravani H, Zamponi GW. Voltage-Gated Calcium Channels and Idiopathic Generalized Epilepsies. Physiol Rev. 2006;86:941-66.

27. Belardetti F, Zamponi GW. Calcium channels as therapeutic targets. WIREs Membr Transp Signal. 2012;1:433-51.

28. Yellen G. The voltage-gated potassium channels and their relatives. Nature. 2002;419:35-42.

29. Wulff H, Castle NA, Pardo LA. Voltage-gated Potassium Channels as Therapeutic Drug Targets. Nat Rev Drug Discov. 2009;8:982-1001.

30. Zucchi R, Ronca-Testoni S. The sarcoplasmic reticulum $\mathrm{Ca}^{2+}$ channel/ryanodine receptor: 
modulation by endogenous effectors, drugs and disease states. Pharmacol Rev. 1997;49:1-51.

31. Smani T, Shapovalov G, Skryma R, Prevarskaya N, Rosado JA. Functional and physiopathological implications of TRP channels. Biochim Biophys Acta. 2015;1853:1772-82.

32. Rahman MS, Kwon WS, Pang MG. Calcium Influx and Male Fertility in the Context of the Sperm Proteome: An Update. 2014:841615.
33. Kaupp UB, Seifert R. Cyclic Nucleotide-Gated Ion Channels. Physiol Rev. 2002;82:769-824.

34. Decoursey TE. Voltage-Gated Proton Channels and Other Proton Transfer Pathways. Physiol Rev. 2003;83:475-579.

Cite this article as: Jacob NT. Drug targets: ligand and voltage gated ion channels. Int $\mathrm{J}$ Basic Clin Pharmacol 2017;6:235-45. 